\title{
A SZEGÉNYSÉG KISAJÁTíTÁSA ÉS SZIMBOLIKUS ÚJRAKERETEZÉSE: AZ „ÉRDEMTELENEK" RASSZIZÁLÁSA ÉS AZ „ÉRDEMESEK” ETNICIZÁLÁSA. GYÖNGYÖSPATA TANULSÁGAI'
}

\section{SYMBOLIC APPROPRIATION AND POLITICAL REFRAMING OF POVERTY: THE RACIALIZATION OF UNDESERVING AND ETNICIZATION OF DESERVING POOR. LESSONS OF THE GYÖNGYÖSPATA CASE 2011}

\author{
Feischmidt Margit' ${ }^{1}$ Szombati Kristóf ${ }^{2}$ \\ 'PhD, tudományos tanácsadó, MTA Társadalomtudományi Kutatóközpont Kisebbségkutató Intézet \\ Feischmidt.Margit@tk.mta.hu \\ ${ }^{2} \mathrm{PhD}$, vendégtanár/visiting professor, Columbia University, New York, USA \\ ks3604@columbia.edu
}

\section{ÖSSZEFOGLALÁS}

Az elmúlt évek tapasztalatai azt mutatják, hogy Kelet-Európában, és különösképpen Magyarországon, a társadalmi és politikai status quóval szembeni lázadás egyik módja a szegények érdemtelenekre és érdemesekre való felosztása. Ennek a folyamatnak meghatározó része az érdemtelenek rasszizálása és elidegenítése a társadalom rasszjegyektől jelöletlen részétől; továbbá az érdemes szegények kulturális, historizáló keretek közötti felértékelése. Esettanulmányunkban azokat a társadalmi körülményeket és gazdasági viszonyokat vizsgáljuk, amelyek a rasszizált szegények kizárására épülő beszédmódot és politikát elfogadhatóvá tették.

\section{ABSTRACT}

By a qualitative case study this paper offers social and economic explanations of the success of the populist far-right on the local level. We present how reframing of poverty, creating the social distinction between two categories of the poor - the racialization of underserving and the culturalization of deserving poor - becomes part of this political process.

Kulcsszavak: szegénység, érdemesség, érdemtelenség, etnicitás, rasszizmus, helyi politika, szélsőjobboldali politika, romák

Keywords: poverty, worthiness, unworthy, ethnicization, racialization, far-right politics, Roma, Hungary

${ }^{1}$ A gyöngyöspatai eset átfogóbb elemzését két változatban írtuk meg, lásd Feischmidt-Szombati, 2017a, 2017b. 


\section{BEVEZETÉS}

Tanulmányunkkal a szegénység politikai tematizációjának kérdéséhez szólunk hozzá. Azt az általános jelenséget mutatjuk be egy konkrét példán keresztül, hogy a szegények képviseletében fellépő politikai szereplők - jellemzően olyanok, akik magukat a szegényeken kívül helyezik el - a szegénység kérdését társadalmi kizárólagosságok megteremtésére használják fel. Egyik irányban az érdemes és érdemtelen szegények kategóriáinak megteremtésével lefelé húznak meg társadalmi határokat, és hozzák létre az elismerésre és támogatásra méltó szegények kategóriáját. Másik irányban az establishmenttel szemben húznak határokat, rámutatva arra, hogy a régi elitek és az általuk létrehozott strukturális és hatalmi viszonyok miként vezettek a munkához vagy jövedelemhez jutás lehetőségeinek beszüküléséhez, vagyis a szegénység kiterjedéséhez. A két politikai stratégia egyesítése a szélsőjobboldali aktorok sajátossága az egész világon, aminek népszerüségéhez, társadalmi támogatottságához azonban nemcsak a kínálati oldal, hanem a kereslet is hozzájárul, amire a társadalomtudományok elsősorban strukturális magyarázatokat adnak.

A szegények újabb csoportja a gazdasági és társadalmi átalakulási folyamatok veszteseiből kerül ki, amely folyamatok egyrészt az ipar és mezőgazdaság leépülésével, illetve átalakulásával, másrészt a globalizációval függnek össze. Egy kétirányú osztálydinamika feszíti szét a társadalom középrétegét, amelynek továbbra is prosperáló része képes a technológiai fejlődéssel és a globalizáció elvárásaival lépést tartani, azok pedig, akik nem képesek erre, relatív státuszvesztést élnek meg. A modernizációs elméletek szerint a posztindusztrializáció a kulturális tőkével rendelkező, identitásukat tekintve adaptív fehérgalléros munkavállalók számára inkább kedvező; az ipari munkához egzisztenciálisan kötődő kékgalléros munkavállalók számára inkább kedvezőtlen hatással van. Miután a társadalmi viszonyokat meghatározó legfontosabb folyamatokról van szó, akik ezt sikeresen tematizálják a politika meghatározó szereplőivé tudtak/tudnak válni. A kétféle kizárólagosság, lehatárolás és kizárás közül pedig az adott helyezetnek és saját hatalmi érdeküknek megfelelően választanak.

Kelet-Európában ehhez még hozzáadódik a „félresikerült rendszerváltások” nyomán eröre kapó elit- és általános rendszerellenesség, valamint a rend és az erőskezű vezetés iránti igény ezzel párhuzamos növekedése. Az elöítéletek és a jóléti sovinizmus skáláján is kelet- és dél-európai országok a csúcstartók. A szélsőjobboldali populizmus mozgásterét Kelet-Európában az a tendencia is növeli, hogy a lakosság túlnyomó része az átmenet nehézségeiért a gazdasági-társadalmi struktúrák helyett bizonyos csoportokat tesz felelőssé. A baloldali fogantatású strukturális kritika gyengesége Kelet-Európában a mélyen rögzött történelmi sztereotípiák térnyerésével, a cigány- és zsidóellenesség felerősödésével járt együtt, amit a szélsőjobboldali pártok tovább igyekeznek erősíteni. A posztkom- 
munista régióban a jóléti juttatások radikális leépítése fontos szerepet játszott a szélsőjobboldal megerősödésében. A neoliberális ihletésű gazdaság- és társadalompolitikai reformokért hevesen bírált baloldali pártok támogatottságának csökkenése szélesebb teret nyitott a szélsőjobboldali politikának (amely, éppen ezért, elutasítóbb a piaci erőket támogató politikával szemben, mint Nyugaton). Ezek következtében Kelet-Európában szélesebb és - néhány kivételtől eltekintve egyre növekvő tömegek váltak fogékonnyá a kisebbség- és elitellenes szólamokat hangoztató, rendpárti fordulatot követelő politikai erők programjára.

Az elmúlt évek tapasztalatai mégis azt mutatják, hogy Kelet-Európában és különösképpen Magyarországon az elitekkel szembeni lázadásnál nagyobb vonzereje van a lefele történő elhatárolódásnak. Ennek egyik módja az érdemtelenek elidegenítése, elkülönítése, a szegények egy részének rasszizálása, másik részének pedig kulturális keretek között történő felértékelése. Ezt a jelenséget mutatjuk be a következőkben egy esettanulmány segítségével, amely a szélsőjobboldalnak a helyi politikában megvalósult győzelme mögött tárja föl a szegénység rasszizálásának és etnicizálásának folyamatait.

A kutatás kvalitatív módszerekkel történt, a következtetések nyilvános adatokra és dokumentumokra, valamint a településen lakó emberekkel készített félig strukturált interjúkra és beszélgetésekre, valamint számos közéleti esemény megfigyelésére épül. A kutatás első szakaszában elsősorban a helyi elitszereplők pozíciójának és véleményének megismerésére törekedtünk. Mélyinterjúkat készítettünk a képviselőtestület és a Cigány Kisebbségi Önkormányzat tagjaival, az események alatt lemondott polgármesterrel, a településen müködő intézmények (óvoda, iskola, művelődési ház) és civil szervezetek (Együtt Gyöngyöspatáért Baráti Kör, Vári Pincék Egyesület, Gyöngyöspatai Vállalkozók Egyesülete) vezetőivel. Az interjúk egy öt kérdésblokkból álló (a személyes életútra és pozícióra; az események megélésére és megítélésére; a múltbeli együttélésre; az együttélés jövőbeni esélyeire; és a közösségi párbeszéd lehetőségére rákérdező) vezérfonal alapján készültek, átlagos időtartamuk 120 perc volt. Az elittel készített interjúkat a faluban élő közemberekkel folytatott beszélgetésekkel egészítették ki, amelyek ugyan kötetlenebb hangvételúek voltak, de követték a vezetői interjúk vezérfonalát. A kutatás második szakasza arra a falurészre koncentrálódott, amely a feszültségek gócpontjának tekinthető (Bajcsy-Zsilinszky utca, Bem utca).

\section{GYÖNGYÖSPATA 2011. A ROMÁK ELLENI MOZGÓSÍTÁS MINT FORMATÍV ESEMÉNY A POLITIKÁBAN}

2010-ben az Országgyülésbe való bekerülését követően a Jobbik Magyarországért mozgalom öndefiníciós problémákkal küzdött. A Fidesz a ciklus kezdetétől fogva szimbolikus lépésekkel (kettős állampolgárság, Trianon-emléknap bevezetése) gyengítette a párt politikai érvényesülési lehetőségeit. A kormánypárt „forradal- 
mi” retorikája és a nyomában megkezdődő átfogó átalakítások a Jobbik radikális változásokra tett ígéretét tették zárójelbe. Az MSZP látványos meggyengülésével és az SZDSZ parlamentből való kiesésével pedig az egyik fö politikai ellenségképét veszítette el a szélsőjobboldali párt. Mindezek következtében 2010 második felében erős válságtünetek jellemezték a Jobbikot. A párt szavazóinak jelentős részét kifejezetten annak mozgalmi karaktere fogta meg. A párt sikerének egyik legfontosabb eleme az a sikeresen keltett benyomás, miszerint a Jobbik a vidéki emberek igényeire alapozza a politikáját, és ezekre az igényekre képes közvetlen módon reagálni. Ezért a Jobbik vezetése szavazói bázisa konszolidálása érdekében a kormánypárttól való markáns megkülönböztetés és a korábban már bevált utcai politizáláshoz való visszatérés mellett döntött. Erre a váltásra alkalmasnak látszott a gyöngyöspatai történet.

Gyöngyöspatán 2010 őszén több roma család házát károsította meg súlyosan egy helyi árvíz. Egy nyolcfös család számára a Vöröskereszt a cigánytelep határán túli, etnikailag vegyesen lakott utcában készült házat vásárolni. Az ennek hatására a faluban kialakult feszült helyzetről rövidesen a Jobbik országos vezetése is értesült. A Szebb Jövőért Polgárőr Egyesület járőrözése pontosan egy héttel azután vette kezdetét, hogy egy idős Bajcsy-Zsilinszky utcai lakos öngyilkosságot követett el. A Jobbikhoz közel álló Barikád TV az esetet követő második napon - február 24-én - riportot adott közre „Cigányterror” - Heves megye a polgárháború szélén áll címmel. Ebben Juhász Oszkár a korábban tervezett, de később lemondott házvásárlási akcióval hozta összefüggésbe az öngyilkosságot. Március 6-ára a Jobbik tömegrendezvényt szervezett a falu föterén, amelyre a helyi lakosokat Demonstráció a cigányterror ellen címü szórólapokkal toborozták. A hozzávetőleg kétezres tömeg részvételével megvalósult demonstráción a pártelnök mellett beszédet mondott a Jobbik helyi vezetöje is. A Jobbik nagygyülése után a katonai jellegü ruházatban felvonuló személyeket is magában foglaló tömeg a cigánysorra vonult, ahol Juhász Oszkár egy Együttélési szabályzat címü, erre az alkalomra írott dokumentumot adott át a Cigány Kisebbségi Önkormányzat vezetőinek. A Jobbikos akciót követően a Magyar Gárda és a településen tartózkodó polgárörök még tíz napon át ,járőröztek”. A rendörök, bár folyamatosan és nagy számban a helyszínen tartózkodtak, ekkor sem avatkoztak közbe. Az egyenruhát viselö férfiaktól a roma gyerekek különösen rettegtek, de a felnöttek is félelemmel és szorongással élték meg ezeket a napokat. A 2011 tavaszán a faluban megjelenő paramilitáris és szélsőjobboldali politikai szervezetek, és az ennek során elszabaduló ellentétek kikezdték a helyi hatalom már korábban megrendült intézményeit, azokat a hálózatokat, amelyeknek korábban fontos szerepük volt a társadalmi stabilitás fenntartásában. A bizalmatlanság általánossá vált - nem csupán a kisebbségi és többségi lakosság viszonyában, de a kisebbségi és többségi csoporton belül is. A falu választott polgármestere társadalmi támogatottság hiányában lemondott, ami a szélsőjobboldali politika előtt szabaddá tette a ha- 
talom megragadásához vezető utat. A rendkívüli önkormányzati választásokon a Jobbik jelöltje által elért választási siker kulcsának pontosan ez a szétziláltság bizonyult. Bármilyen erősnek is gondolták magukat az ellenjelöltek, ahhoz nem voltak elég erősek, hogy a Jobbikkal szemben egy másik alternatívát győzelemre vigyenek. Nyilván azért sem, mert többen a lokálpatriotizmus mellett a cigányok elleni radikális fellépést támogatták. Akik nem, azok meg bizonytalanok voltak, a kormánytól vártak támogatást, és nem egymással keresték az együttmüködést. Minden bizonnyal féltek attól is, hogy antirasszista pozíciót vegyenek fel, mert érzékelték, hogy azzal könnyen a faluközösség perifériájára sodródhatnak.

\section{A FALU}

Gyöngyöspata Heves megye gyöngyösi kistérségében, Gyöngyöstől tíz kilométerre északnyugatra fekszik. Össznépessége a 2001-es népszámlálás idején 2761 fő volt, amiből 324 fó (11,7\%) vallotta magát roma/cigány nemzetiségűnek. A település egy történelmi borvidék része, ahol az államszocializmus idején jól müködő, bár az egri üzemekhez képest másodlagos jelentőségű szőlö- és bortermelés folyt. A rendszerváltás után a szőlészeti és borászati termelőkapacitás erőteljesen megcsappant, a mennyiségi termelésre beállított ágazat válságba került. Ma a borászati ágazatban tíz nagyobb családi vállalkozás müködik. Tulajdonosaik elégedetlenek a politikai és gazdasági környezet nyújtotta lehetőségekkel, aminek fontos helyi társadalmi és politikai következményei vannak. A mezőgazdasági termelés történelmileg mindig is jelentéktelenebb szerepet játszott. A gabonaágazatban egyedül egy húsz alkalmazottat foglalkoztató, hozzávetőleg kétszáz hektáron gazdálkodó mezőgazdasági cég számít jelentősnek. Az ipari foglalkozatás már a szocializmus idején jelentősebb volt, mint a mezőgazdasági. Akkor a gyöngyösi vállalatoknál (Egyesült Izzónál, bútorgyárban, vágóhídnál) és a közeli településeken található szén- és ércbányáknál (Visonta, gyöngyösoroszi ércbánya, gyöngyösoroszi és szücsi szénbánya) dolgoztak a legtöbben, de a budapesti építőtelepeken is. Ezekben az ágazatokban dolgoztak a patai romák; férfiak és asszonyok is. A munkanélküliség - egy korábbi faluvezető információi alapján a nagy foglalkoztatók megszünése óta nagyjából állandó szinten van, körülbelül 100 fő körül mozog. A romák és többségiek aránya a munkanélküliek között 80-20 százalék (tehát nagyjából fordított arányú a teljes lakosság etnikai összetételéhez képest). A helyi munkaerőpiaci viszonyokat értékelő vezető szerint a romák túlreprezentáltságának oka a munkanélküliek között az, hogy a „romák nem tudtak az önállóság útjára lépni”, miközben a többségiek jelentős része az építőipar, különböző szolgáltatások vagy a mezőgazdaság területén önfoglalkoztatóvá vált. Egyetlen roma vállalkozó van a faluban (akit sokan nem is tartanak romának). E család két helyben élö tagján kívül állandó munkaviszonya három 
roma férfinek van. További négy-öt főt a helyi többségi szőlősgazdák rendszeresen alkalmi munkásként foglalkoztatnak. A gyöngyöspatai romák foglalkoztatási adatai sokkal rosszabbak a teljes roma népesség adatainál.

\section{STRUKTURÁLIS EGYENLŐTLENSÉGEK ÉS A SZÍNHATÁR MEGERŐSÖDÉSE}

A többszörös kitaszítottság és a belőle fakadó kisebbségi sérelmek ellenére több elemző, köztük a kisebbségi ombudsman is, úgy találta, hogy „mielőtt az egyenruhások a településre érkeztek volna, nem volt jelentősebb feszültség a falu roma és nem roma lakosai között”. Azt követően azonban ,a helyi társadalom kettészakadt”. Ezzel szemben állt az a szélsőjobboldali médiumokból származó, de később sokkal szélesebb körben elterjedt vélekedés, miszerint a faluban élő romák deviáns viselkedése hosszú ideig tartó elfojtás után lett nevén nevezve, vagyis amit mások „konfliktusnak” hívnak, az valójában, csak a többségi igazságtétel pillanata volt. Mi úgy látjuk, hogy a gyöngyöspatai konfliktus hátterében a kisebbségi és többségi lakosok együttélését terhelő, a rendszerváltás óta eltelt húsz év során felgyülemlett, de korábbi előzményekkel is bíró problémák állnak. Ezek között első helyen a helyi többségiekhez hasonlóan korábban elsősorban az iparban foglalkoztatott romák munkaerőpiacról való kikerülése és tartós távolmaradása említendő. Miközben a foglalkoztatás települési szinten nem rendelkezik rossz mutatókkal, vagyis azt látjuk, hogy a gyöngyöspataiak nagy többsége a környezö üzemekben el tudott helyezkedni, illetve a visszakapott földeken kisebb - gyümölcstermesztésre, szőlőművelésre és borászatra szakosodott - családi gazdaságokat müködtet, a helyi romák sem egyikben, sem másikban nem tudtak megkapaszkodni. A cigányok jelentős részének legnagyobb sérelme az, hogy nem jutnak munkához. Ez a sérelem a 2011-es tavaszi eseményeket követő hónapokban tovább fokozódott, mert azok a foglalkoztatók, akik addig romákkal dolgoztak, a többségi közvéleménytől tartva nem alkalmazták őket tovább.

A másik sérelem a lakóhelyi szegregációból fakad, amelyet a helyi vezetés szándékos elkülönítési politikája évek alatt tovább mélyített. A képviselőtestület 2007-ben helyi építési szabályzatban foglalt változtatási tilalmat rendelt el a falu néhány utcájában, amivel egyrészt az ún. „szocpolos” házak építését, másrészt a meglévő, romák által lakott ingatlanok fejlesztését, valamint roma családoknak a falu központjába költözését akarta megakadályozni. A helyi politikában egyre nagyobb befolyásra szert tevő civil szervezet közvetítésével az önkormányzati testületi tagok fel nem vett tiszteletdíját (információink szerint évi tízmillió forintot) a faluban örökös nélkül maradt, vagy más ok miatt eladásra került házak felvásárlására fordították, illetve kiközvetítették a helyi közösség számára veszélytelennek tartott családoknak. Az ingatlanpiaci folyamatokba történő beavatkozást, ami a jogalkotói hatalommal való visszaélés is, azzal legitimálták, 
hogy csak így lehetett ellenállni annak a „veszélynek”, amit a Gyöngyösről - az ottani cigánytelep megszüntetése miatt - kiköltöztetett cigányok, valamint azok jelentettek volna, akik „lenyúlják a cigányok szocpolját”. Ez, a kezdetben egy elitcsoportosulás által képviselt törekvés találkozott többségi lakosok véleményével, és egyúttal megalapozta azok hatalmi aspirációit, akik a „cigányok” kontroll alatt tartását fontos közösségi ügynek tekintették. Az intézkedés a gyöngyöspatai romák szempontjából az önrendelkezés korlátozásával, az előrejutás megakadályozásával volt egyenlö.

Az egyenlőtlenség legfontosabb tényezőjeként említett munkaerőpiaci szegregáció nemcsak a közvetlen diszkriminációra, hanem az iskolázottsági különbségekre is visszavezethető. A patai romák alacsony iskolázottságának az okát elsősorban a helyi iskola alacsony hatékonyságában látjuk. A roma gyerekek túlnyomó része speciális osztályba vagy egy speciális nevelési igényü (SNI) gyerekekkel összevont szegregált osztályba járt, amikor 2011-ben hosszabb ideig a faluban tartózkodtunk, és ez az állapot azóta sem sokat változott. A külön osztályba sorolás térbeli elkülönítéssel párosul, a speciális „B” osztályok az iskolaépület földszintjén, a „normál” osztályok az emeleten kapnak helyet. A cigány gyerekek és a nem cigány tanulók külön mosdóhelyiséget használnak. A napközis ellátást azok vehetik igénybe, akiknek az édesanyja dolgozik, a roma gyerekek többsége ily módon kimarad ebből a szolgáltatásból. A „normál” osztályok a sportórák megadott részét az iskolához tartozó uszodában töltik, ugyanez a lehetőség a speciális osztályok tanulói számára nem adott. A roma gyerekeket az iskolai ünnepségek programjába is messze iskolai számarányuk alatt vonják be. Az iskolai szegregáció, amelynek a tényét az Esélyt a Hátrányos Helyzetủ Gyerekeknek Alapítvány (CFCF) feljelentése nyomán indult szegregációs perben a bíróság megerősített, két célt szolgált. Egyfelől azoknak a konfliktusoknak az elkerülését, amelyeket a pedagógusok nem tudtak kezelni, másfelől azt a társadalmi igényt, amely a többségi gyerekeket meg akarta óvni a cigány tanulókkal való vegyüléstől. Az iskolavezetés úgy vélte, hogy az elkülönítés biztosítása a feltétele annak, hogy a „magyar gyerekeket” ne vigyék el a közeli, városi iskolákba. Az iskolaigazgató saját feladatát abban látja, hogy ezt az iskolai rendet, amely elmondása szerint a „magyar” és a cigány gyerekeknek egyaránt jó, megvédje a jogvédőkkel szemben.

A szegregáció három fent említett, intézményesült és erőteljes strukturális következményekkel bíró formája szinte lehetetlenné teszi, hogy az iskolázatlanságot, munkanélküliséget és legrosszabb lakáskörülményeket jelentő „cigány” státuszból Gyöngyöspatán ki lehessen törni. Próbálkozások vannak ugyan, de nagyon keveseknek sikerül a kiemelkedés. „Elveszítik a hitüket, nincsen elég akaratuk” - véli a „cigány futballválogatott” Gyöngyöspatáról elszármazott edzője, a Rajkó Zenekar korábbi vezetője, akinek példája azonban nem tud ösztönzővé válni. Azért nem, mert a mobilitás útjait Gyöngyöspatán a többségi vezetés diszkurzív és közpolitikai eszközökkel „,csendben” elzárta. 


\section{A „PARASZTOK” SÉRELMEI A KÖZÉLET KÖZÉPPONTJÁBA KERÜLNEK}

Gyöngyöspatán azonban nemcsak a romáknak vannak sérelmeik, hanem a többségieknek is. Különösen a többséghez tartozó szegényeknek, akik ugyancsak kiszolgáltatottak, társadalmi helyzetük sérülékeny. Az a diskurzus azonban, amely ezek köré a kétségtelenül valóságos, mégiscsak egyedi esetek köré szerveződik, tárgyát tekintve általánosító, használatát tekintve pedig sokkal szélesebb körben elterjedt, mint azt a tényleges sértettek száma indokolná. Megteremti a többségi normákat semmibe vevő, a rendet felforgató, a „magyarokra” nézve éppen ezért veszélyt jelentő cigányok képét. A sztereotípiák ugyanazok, mint amelyek széles körben elterjedtek a teljes magyar társadalomban, attól valósabbak és hatásosabbak azonban, hogy olyan történetek kapcsolódnak hozzájuk, amelyek kárvallottjai és olykor elkövetői is a beszélők számára ismert emberek. Fontos megjegyezni, hogy a többségi sérelmek erőteljes kanonizációs folyamaton mentek át. Ennek kulcsmomentuma a korábban említett civil szervezet vezetöje által 2006-ban összeállított hetvenoldalas panaszlista volt, amelyet az illető a rendőrséghez, a helyi képviselőtestülethez és a térség országgyülési képviselőjéhez is eljuttatott. Az a tény, hogy ez a „petíció” válasz nélkül maradt, nagymértékben hozzájárult az említett szervezetek legitimitásának eróziójához és az érintettek cigányellenes indulatainak felerösödéséhez.

„Az ellentétet az szítja, hogy nem dolgoznak a romák. Ez irritálja ez embereket" - mondta egy faluban lakó ember, majd a meglátása szerint egyre gyakoribbá váló lopásokról kezdett el beszélni. Példaként ő is - mint a pataiak többsége - a Kecskekőt említette elsőnek, talán azért, mert „ott termett a legszebb szőlő". A cigánytelep mögötti dombon található takaros víkendházak és jól termő hétvégi kertek lepusztulása nem csak a tulajdonosok számára fájdalmas. Az elhagyott, majd a romák által „széthordott” kertek mindennapi látványa a falu többségi lakóit a rendszerváltás utáni nehézségekre (a késő szocializmusra jellemző biztonság elpárolgására, a sokszor hiábavalónak tűnő fáradozásra), valamint a büszkeség tárgyát képző paraszti tradíciók folytathatatlanságára emlékezteti. A paraszti becsületet mélyen sértő tüskét elviselhetetlenné az teszi, hogy a „Bajcsiban épült szocpolos házak tetején kötöttek ki a Kecskekőn szétszedett pincék cserepei”. Egy másik adatközlő szerint „a kis lopásokkal korábban nem volt probléma, mert nem számított az embereknek 20 kiló gyümölcs, de most már nem jó a parasztok helyzete sem, ezért már a pataiak sem olyan toleránsak, mint régen". Azt is meg kell azonban említeni, hogy a Kecskekő pusztulásának van egy másik, számszerü kisebbségben lévő többségiek és romák által osztott olvasata, miszerint mindenki számára tudott volt, hogy a Kecskekővel „nem érdemes vesződni” azután, hogy a falu határában máshol nagyobb kiterjedésű, jól megközelíthető földeket kaptak vissza a korábbi tulajdonosok. Egy biztos: amíg nem lett médiahír, nem okozott botrányt, az emberek jelentős része beletörődés- 
sel kezelte, részeként egy sokkal általánosabb folyamatnak, a késő szocializmusra jellemző stabilitás szétesésének.

A sérelmek általánosítását azok a szóváltások is elősegítik, amelyek a verbális agresszió megnyilvánulásaként értelmezhetőek. A többségiek, kiváltképpen az idős parasztasszonyok és férfiak, akik a roma fiatalokhoz hasonlóan több időt töltenek az utcán, tiszteletlenségnek érzékelik azt a viselkedést, amelyről maguk is tudják, hogy néhány tizenéves fiúra jellemző, mégis a cigányságra általánosítják. (A fiatalok viselkedését mi a társadalmilag kiszolgáltatott, gettójába visszaszoruló csoport hétköznapi ellenállásaként is értelmezzük, amely apró szimbolikus győzelmekkel próbál a helyzetükért részben felelősnek tartott többség legsérülékenyebb tagjain elégtételt venni.) A többségi sérelmi diskurzus nagyon fontos eleme a meg nem értettség vagy méltánytalanság. Sokaktól hallani - föleg az alacsony fizetésért dolgozó, de stabil egzisztenciával rendelkező emberektől -, hogy a „cigányok hat gyerekkel munka nélkül” annyi jövedelemhez jutnak, mint ők több évtizedes megszakítatlan munkával. Mint említettük, a „magyarok” sérelmeit nem vette komolyan a jegyző, a rendőr, a bíróság. Az állam iránti bizalom hiánya és a gyanakvás nagymértékben meghatározta a 2011 tavaszi konfliktus feldolgozását és elbeszélését a többségi oldalon: „a magyarokra nem figyelt se Pintér, se a média", nem úgy, mint a cigányokra, akik a domináns többségi felfogás szerint ,„a felfordulást” okozták. Sőt, mi több, a külső segítség és támogatás különböző formái is csak a cigányokhoz érkeztek, akik „loptak, csaltak, és jutalomból még el is vitték őket nyaralni”. A cigányokkal való „túlfoglalkozás” mellett a „magyar falu” érdektelenné vált sok kívülálló számára. A sérelmi diskurzus legfontosabb jellemzője, hogy kizárólagosságot teremt: „a mi” sérelmeink attól valószerüek, ha tudjuk, kik azok, akik ezeket elkövették. Azokról pedig, akiket a vétkes szerepébe helyezték, elképzelhetetlenné válik, hogy nekik maguknak is sérelmeik lehetnek. Miközben ,a magyarok” sérelmeit felnagyítja ez a domináns többségi diskurzus egyben el is fedi a fent említett strukturális kényszerekből származó panaszokat.

A sérelmekre és elkövetőik megnevezésére fókuszáló többségi diskurzus „,szállítói” a „frontvonal” nagyrészt idős lakói. A diskurzus „multiplikátorai” között azonban - amint azt a Kecskekő kapcsán jeleztük - olyanokat is találunk, akik nem közvetlen sérelmeiket mondják el a „cigánykérdés” nyelvén, hanem saját társadalmi helyzetükre, azzal kapcsolatos problémáikra adnak választ. (A gazdasági helyzet romlásáért, a társadalmi dezintegrációért, a szolidaritás hiányáért - az ország lakosainak többségéhez hasonlóan - nem strukturális viszonyokban keresik a magyarázatot, hanem ellenkezőképpen, azokról a figyelmet elterelik, és egy olyan társadalmi csoportra irányítják, amely ugyanannak a strukturális átalakulásnak a legnagyobb kárvallottja. Közben nyilván megerősítik azt a rendszert, amely a szükös erőforrásokért való versenyben őket is a korábbinál sokkal rosszabb helyzetbe hozta.) Végezetül a többségi diskurzus „legitimátorainak” 
szerepét eljátszó lokálpatrióta elit tagjait kell említeni. Az ő „fordulatuk” mögött - amint azt az alábbiakban elmagyarázzuk - egyfelöl az áll, hogy több tagjuk abban az etnikai frontvonalként értelmezett zónában lakott, ahol a „forró tavasz” előzményei lezajlottak, és többen közülük az utóbbi években fizikailag is konfrontálódtak a telepen lakó romák egy-egy csoportjával. Másfelől a lokálpatrióta elit a cigányellenes indulatok politikai kifejezésében látott módot a problémákat inkább elhallgató, semmint kiélező korábbi politikai vezetés meggyengítésére, majd sarokba szorítására.

A szegregáció által kiélezett strukturális problémák, a belőlük kitermelődő deviancia, illetve annak többségi megbélyegzése („cigánykérdésként”) együttesen eredményezték, hogy a „cigánytelep” és a „falu” határán etnikai frontvonal alakult ki. A „Bajcsin” néhány évtizeddel ezelőtt még csak parasztok laktak, nyilván a szegényebbek. Az utca egyik házsorának kertjei a néhány évente kiöntő patak felé szaladnak le. A patak túlsó oldalán volt már korábban is a cigánytelep (akkori nevén ,cigánypart”). Ez volt az a zóna, ahonnan a kerti lopások történetei elindultak. Az elmúlt évtizedekben a „Bajcsin” eladott ingatlanok egy részét roma családok vásárolták meg, aminek következtében a mindennapi interetnikus viszonyokat illetően folyamatos súrlódások és elfojtás árán létrehozott érzékeny egyensúly jött létre. Vannak, akik emlékeznek még arra, hogy valamikor jobb volt a szomszédokkal való viszonyuk, ma viszont ebben az utcában nem köszönnek egymásnak a többségi és roma szomszédok. A 2011 tavaszi konfliktus előzményeinek tekinthető korábbi konfliktusok - kollektív erőszakról van szó minden esetben nagy része ugyancsak ehhez az utcához (más része a szintén „ütközőzónaként” értelmezett iskolához) kötődik. Az első verekedés 2006-ban tört ki azután, hogy a Bem utcában lakó hegybíró kocsijának a gumiját gyerekek leeresztették, ami meglepően gyorsan vezetett kollektív konfliktushoz. A hegybíró a gyerekre ijesztett, aki ezután elesett, és megindult az orra vére. A nagymama unkája véres arcát látva bosszúért kiáltott. Gyorsan megérkeztek a felbőszült rokonok, és a gyermek bántalmazásával vádolt férfi kapuján dörömböltek. A hegybíró ismerősei a segítségére siettek. A két csoport egyes tagjai összeverekedtek, az időközben a helyszínre érkezett kommandósok választották szét őket. Az incidensnek sérültje is volt ugyan, politikai következménye azonban annál jelentősebb: falugyűlést tartottak, ahol hangot kapott a cigányellenesség, ami a lokálpatrióta civilek közül kinőtt önkormányzati képviselőjelöltek támogatottságát növelte. Egy két évvel későbbi incidensre a többségi adatközlők úgy emlékeznek, hogy egy „cigány kocsi” elsodort egy „magyar fiút”. 2009-ben egy tanárnőt megütött egy cigányasszony (ugyanaz a nagymama, aki a 2006-os verekedésben is kulcsszerepet játszott), mert tudomására jutott, hogy az unokáját bántalmazták az iskolában. A szegregáció intézményesítése miatt egyébként is előtérbe kerülö iskola ezen a ponton involválódott a konfliktusok menetébe, miközben a szereplök (például a tanárnő) még mindig a „Bajcsi” környékén lakók voltak. 


\section{AZ ÉRDEMESEK ETNICIZÁLÁSA ÉS EGY ÚJ HELYI ELIT GYŐZELME}

Gyöngyöspatán sokan vannak, akiknek felmenői több száz évre visszamenőleg a faluban éltek. Sohasem volt jelentős az elvándorlás (a bevándorlás sem), a ma itt élők jelentős része a régi parasztcsaládok, bortermelő nagygazdák leszármazottja. A faluban népdalkör múködik, a hagyományos paraszti viseletet a szocializmus időszakára eső „kivetkőzés” után újra megvarrják, és egyre gyakoribb, hogy ünnepek alkalmával fel is veszik. A falu magasan iskolázott alkalmazottakból és vállalkozókból álló elitje esetében a patai hagyományok megőrzésére és felélesztésére törekvő lokálpatriotizmus a helyi gazdaságfejlesztés szándékával párosul. A faluban három civil szervezet is müködik, amelyek közül kettő a borászat, a turizmus, a helyi müvészeti tevékenységek támogatására, a hozzájuk kötődő események megvalósítására irányul. Azok számára, akik a régi magyar falut akarják 21. századi körülmények között helyreállítani, a cigányok jelenléte problémát jelent, ugyanis a „renitenskedő”, a falu köztereit „elfoglaló”, növekvő számú és számarányú cigányság jelenléte megakadályozza a helyi fejlesztőket abban, hogy a falut olyanná tegyék, amilyennek ők szeretnék látni.

A lakóhelyi szegregáció megerősítésében és intézményesítésében, a „színhatár felállításában" meghatározó szerepe volt az egyik helyi civil szervezetnek, amelynek ösztönzésére az ingatlanokra és lakóhely-változtatásra vonatkozó tilalmat - az állam törvényei ellenében - helyben törvényesítették. Ugyanehhez a „baráti körhöz” tartozik az iskola jelenlegi igazgatója is, aki a „színhatárt” az iskolában is felállította. A civil szervezet tagjai diplomás emberek, sok-sok buzgalommal és a faluért való tenni akarással, akik azonban néhány évvel ezelött a falu közéletében még nem voltak meghatározó szerepben. Kezdetben csak kívülröl gyakoroltak nyomást az önkormányzati testületre, mintegy ,,árnyék önkormányzatként" müködve, majd mind többen kerültek az önkormányzat meghatározó pozícióiba. Népszerüségüknek jót tett a cigányokkal szembeni - akkor még radikálisnak tünő - fellépés. Elsősorban a faluban élő idős parasztok szimpátiáját nyerték el, akik közül sokan a rendszerváltás veszteseinek érezték magukat, és szimpátiával figyelték a falu felélesztésén munkálkodó vállalkozókat. Ez a csoport az időseken kívül a konfliktuszóna lakóiban is támogatókra talált, akik hozzájuk hasonlóan úgy érezték, hogy - a cigányokkal ellentétben - az állam őket cserbenhagyta. A civil szervezet legerősebben motivált tagjaivá azok váltak, akik maguk is konfliktuszónában laktak, és érintettek lettek az incidensekben.

A szegregációs intézkedések, a mindennapi beszédben hosszú ideig rejtett, különböző helyzetekben mégis elő-előtörő cigányellenesség, a romák lázadásának hétköznapi, inkább bosszantó, semmint igazán felforgató formái, a határként, és egyben frontvonalként müködő zónában vissza-visszatérő incidensek, és nem utolsósorban a többségiek fülében ketyegő „népesedési bomba” olyan feszültséggócot hoztak létre, amely rendkívül sérülékennyé tette az interetnikus együttélés 
hosszú évtizedekre beállt mintáit. A sérülékenységhez az a legitimációs válság is hozzájárult, amelyet az eliten belüli viszonyok megromlása vont maga után. Néhány évvel ezelőtt hirtelen meghalt az a polgármester, aki jelentős társadalmi támogatottságnak örvendett. Halálát máig a lokálpatrióta civilek tevékenységével hozzák összefüggésbe, akiknek azonban ezt követően sem sikerült formálisan - választások révén - annyi hatalomhoz jutniuk, mint amennyit maguknak vindikáltak. A 2010-ben megválasztott polgármester, aki a helyi vállalkozók többségének és a borászok egy részének támogatását élvezte, úgy igyekezett saját támogatottságát megteremteni és a falu müködőképességét megőrizni, hogy a többnyire látens, de egyre nyilvánvalóbb „cigánykérdéssel” nem foglalkozott. Belátta, mint némelyek ma is, hogy a problémáknak nem kulturális, hanem strukturális okai vannak (elsősorban a munkanélküliség), és mivel azokon nem tudott változtatni, inkább félretette az egyre nyilvánvalóbb problémát. Nemcsak a többségi sérelem emlékezet által regisztrált apróbb lopásokat negligálta, hanem a nagyobb problémákat is: a munkanélküliség nyomában érkező gyermekszegénységet, a pedagógusok cigány gyerekekről való fokozatos lemondását, a romák érdekérvényesítő képességének gyengeségét és a többséghez tartozók növekvő türelmetlenségét velük szemben. A saját hatalmukat a cigányok kontrollálásán keresztül megerősítő csoporttal szemben viszont a mozgás szabadságát képviselte. Ennek fényében szüntette meg a képviselói tiszteletdíjak átutalásának említett gyakorlatát - ezzel kivívva a „baráti kör” radikálisabb tagjainak rosszallását. Ezt a tabut törte meg még 2010-ben az a fiatalember, akit „,a cigányok” által elkövetett egyik incidens sértettjeként ismert meg a falu, majd a szélsőjobboldali párt polgármesterjelöltjeként tört be a közéletbe. Magányos volt, a falu elitje az állami borászati vállalat sikertelen privatizációjában játszott szerepe és alacsony státusza miatt megvetette. Ugyanakkor paradox módon az elitnek szüksége is volt rá, mert személyében és törekvéseiben eszközt láttak saját célkitüzéseik megvalósításához. Akkor történt áttörés a karrierjében, amikor a falut a maga sérelmeivel felkínálta az országos szélsőjobboldali politika és média számára, illetve öt magát felfedezte az országos politika saját céljai számára.

Gyöngyöspata sok tekintetben sajátságos, sok tekintetben viszont éppen olyan, mint a legtöbb magyar falu. A rendszerváltás után gazdasági helyzete megrendült, de a magyar falvak többségéhez képest elég gyorsan talpra állt. Ez a megállapítás a népességnek egy részére nem áll, a patai romákat az országos átlagot messzemenően meghaladó munkanélküliségi arány jellemzi. A foglalkoztatás egyenlőtlenségeinek az államszocializmus idején bekövetkezett kiegyenlítődését, vagyis a gazdasági integrációt nem követte a képzettség hasonló mértékü növekedése, ami a roma közösség tagjai számára lehetővé tehette volna, hogy a piacon stabil, legális munkalehetőséghez jussanak. A gyöngyöspatai romák foglalkoztatása ahhoz a másodlagos munkaerőpiaci szegmenshez kötődött, amelynek megszünése piaci körülményekhez alkalmazkodni képtelen, kiszolgáltatott tömegeket hagyott 
maga után, akiket ráadásul nemcsak ez a fajta strukturális, hanem mindennapi diszkrimináció is sújt. (A faluban évtizedekre visszavezethetö - hol látensebb, hol virulensebb formában müködő - cigányellenességnek, mint mindenféle más rasszizmusnak, nyilvánvaló gazdasági következményei is vannak.)

A strukturális egyenlőtlenség, amely elsősorban a romákat sújtja, a lázadás sokkal inkább egyéni, mint közösségi formáit hívja elő. Ennek kárvallottja a többség, illetve annak leginkább kiszolgáltatott része (idősek, egyedülállók). Magyarországon azonban mindezidáig nagyon ritka volt, hogy az ilyen különbségek és ellentétek kollektív konfliktusok okaivá vagy magyarázó tényezőivé váljanak. Az általunk feltárt közelmúlt azt mutatja azonban, hogy ettől eltérő folyamat indult el Gyöngyöspatán az utóbbi tíz évben. Itt a személyközi incidensek gyorsan csoportos konfliktussá váltak, és azok rögvest etnikai értelmezést nyertek. Mindezeknek nem lett azonnali súlyos következményük, távlati kihatásuk viszont igen. A szelepek, amelyek a feszültségeket levezették, illetve azok a rejtett mechanizmusok, amelyek a konfliktuskezelés spontán formáit müködtették, egyre inkább kiiktatódtak. Ahol az erőszak szabad utat talál, ott a többségi-kisebbségi viszonyt a kölcsönös félelmek és ellenszenvek diktálják. Meglazulnak a kisebbségi-többségi viszonyt egyensúlyban tartó kötőelemek, aminek következtében a közösség kiszolgáltatottá válik mind a szélsőségesnek tekintett elemekhez (utcai balhézókhoz, iskolai verekedőkhöz, gyenge idegzetű nagymamákhoz) kötött ,atrocitásokkal", mind a fokozódó ellenszenv meglovagolásával kísérletező hatalmi érdekekkel szemben. A törékeny egyensúlyért felelős normák érvénytelenné válnak, a korábban kordában tartott indulatok a felszínre törnek, az etnikai csoportok tagjai egymással direkt konfrontációba kerülnek. Ennek a negatív spirálnak Gyöngyöspatán a rendőrség - habár késleltetett - fellépése vetett véget.

\section{ÖSSZEGZÉS}

A 2011-es gyöngyöspatai konfliktus kirobbanásával kezdődő, majd egy helyi szélsőjobboldali „rend” kialakításával folytatódó eseménysorozat legfőbb okának a szélsőjobboldali erők legitimációs igényét és társadalmi mobilizációs erejét látjuk. A konfliktus kirobbanásához minden kétséget kizáróan a félkatonai szervezetek és a Jobbik képviselőinek kisebbségellenes uszítása, valamint a többségi társadalom rendpárti üzenetek melletti mozgósítása vezetett. Amint tanulmányunk elején részletesen kifejtettük, a 2010-ben parlamenti mandátumokhoz jutott Jobbik számára Gyöngyöspata abba a stratégiába illeszkedett, amelynek révén a korábbi időszakra jellemző parlamenten kívüli politizáláshoz kísérelt meg - sikeresen - visszatérni. A szélsőjobboldali párt retorikájában központi szerepet játszó „cigánykérdésben” egy „,valóságos” rendpárti alternatívát akart felmutatni, amit Gyöngyöspatán előbb az utcák, majd az önkormányzat elfoglalásával való- 
sított meg. A párt számára jelentős népszerüségnövekedést hozó „gyöngyöspatai hadjáratnak" kettős üzenete volt a társadalom felé: a Jobbik meg fogja védeni a kormány által cserbenhagyott vidéki lakosságot a „bünöző cigányokkal” szemben, mi több, van elég elszántsága és ereje a cigányellenes retorikából következő politikai program megvalósítására.

Elemzésünkben arra is rámutattunk, hogy a gyöngyöspatai konfliktus kibontakozásában az események során mindvégig kezdeményező szerepet játszó szélsőjobboldali mozgósításon - és azt lehetôvé tevő korlátozott és késleltetett rendőrségi beavatkozáson - túlmenően a cigányellenesség megfogalmazásából és a cigányok megfegyelmezéséből politikai tőkét kovácsoló helyi elit is fontos szerepet játszott. A szélsőjobboldali mobilizáció azért tudott sikeres lenni, mert olyan érzelmeket, észleléseket, attitüdöket és szimbólumokat tudott mozgósítani, amelyek már meglévő társadalmi igényekre és érdekekre épültek, illetve azokra reagáltak.

Azok a civil szervezeti ernyő alatt fellépő helyi „,politikai vállalkozók”, akik a „cigánykérdést” a 2000-es évek derekán előhúzták abból a tabuzónából, ahová a helyi politikai közélet konszolidált vezetői (pártállástól vagy pártszimpátiától függetlenül) korábban számüzték, ugyanazzal a stratégiával kísérleteztek, mint amelyet a Jobbik évekkel később az országos politika szintjén sikerrel alkalmazott. A homogén tömbként kezelt „,cigánysággal” szembeni félelmek megszólaltatása, a személyes sérelmeknek a magánszférából a politikai közéletbe való beemelése - és ezzel együtt a „magyarok” szimbolikus kárpótlása - a politikai tőkeképzés rendkívül hatékony eszközének bizonyult. A tabuk ledöntésével viszonylag rövid idő alatt a falu elitjének perifériájáról a középpontjába lehetett kerülni. Azt állítjuk, hogy e nélkül az ideológiai munka nélkül a szélsőjobboldali mozgósítás nem lehetett volna ilyen sikeres Gyöngyöspatán. Elemzésünkben azt is hangsúlyoztuk, hogy a retorikai fordulaton túl ennek a politikának a lényege a lakóhelyi és iskolai szegregáció intézményesítésében rejlett. A „színhatár” felállításával a gyöngyöspatai települési elit az ország törvényeit figyelmen kívül hagyó rendszert vezetett be, és e tekintetben sokkal tovább ment el, mint a települési vezetések túlnyomó része.

Mindezidáig amellett érveltünk, hogy a gyöngyöspatai konfliktus kibontakozásában legfontosabb szerepe a szélsőjobboldali politikai mozgósításnak volt. Pontosabban azt állítottuk, hogy a korlátozott és késleltetett állami beavatkozás miatt a szélsőjobboldali párt országos és a gyöngyöspatai elitcsoportosulás helyi érdekei között olyan összefonódás jött létre, amely a konfliktus lefolyása szempontjából meghatározónak bizonyult. Ahhoz azonban, hogy a szélsőjobboldali politikai mozgósítás sikeres legyen, nem volt elegendő az elit szándéka és a megfelelő politikai környezet. Ehhez olyan strukturális - társadalmi-gazdasági és kulturális - feltételek voltak szükségesek, amelyek kellő táptalajt nyújtottak a társadalmi problémákért a roma közösség tagjait okoló kisebbségellenes mozgósítás számára. 
A strukturális okok tekintetében kettőt elemeztünk behatóbban. Ezek közül az egyik a kisebbség munkaerőpiacon tartósan kívül rekedt, mélyszegénységben és szegregált lakókörülmények között élő, számszerüleg meghatározó csoportjának visszaszorulása a „gettóba”, majd szembekerülése a kudarcaikért felelősnek tartott többséggel. A másik pedig a lecsúszó falusi középréteg megkapaszkodása egy olyan ideológiában, amelyik nem csupán a lenézett kisebbségtől való szimbolikus megkülönböztetést, hanem - a „magyarság” felértékelése révén - a társadalmi pozícióvesztés által megingatott „paraszti becsület” visszaszerzését is lehetővé teszi.

Az etnikai konfliktusok kutatói a konfliktusokat kiváltó vagy azoknak megágyazó körülményekről általában kétféleképpen gondolkodnak. Vagy a kulturális különbségeket és az azokban rejlő antagonizmust emelik ki, vagy az osztályellentéteket. Mi a konfliktus hátterének vizsgálata során mind a strukturális, mind a kulturális tényezők szerepét igyekeztünk feltárni. Egyfelől rámutattunk arra, hogy a konfliktus két oldalán nem a „romák” és „többségiek”, hanem a „gettóba" visszaszorított mélyszegények és a deklasszálódás és elszegényedés által fenyegetett falusi alsó középosztály álltak. (Ennek megfelelően az események fő kárvallottjai az osztálypozíciójuk mentén a többséghez közel álló, de származásuk miatt „büntetett” „falusi” cigányok voltak.) Azt is jeleztük, hogy a konfliktus táptalaját képező problémáknak egy része (például a romák kiszorulása az elsődleges munkaerőpiacról, a kisüzemi mezőgazdasági árutermelés válsága) az erős osztálypreferenciákat érvényesítő országos gazdaságpolitika, egy másik része pedig a társadalmi mobilitás lokális csatornáit elzáró helyi elit felelőssége. Ezek miatt kerülhettek szembe egymással a lokális gazdaság és önkormányzat szűkülő erőforrásaiért versengő falusi gettó lakosai és az elszegényedő parasztság képviselői. A jelképes és fizikai margóra szorítást a mélyszegények nem hagyták válasz nélkül. Miközben a cigánytelepről az említett korlátozások ellenére kitörni képes családokra az igazodás nyelve és attitüdje jellemző, a „telepiek”- és föként a fiatalok - kultúráját a szegénység és a többség által dominált intézményekből való kiszorítás mindennapi élménye határozza meg. Az ehhez való viszonyulás módjai a lázadás, az ugratás, a bosszantás. A gyengébb fél egyes tagjai azért folyamodnak ezekhez az eszközökhöz, hogy az erősebb fél sérülékenyebb pozíciójú (például idős) tagjai fölött jelképes győzelmeket arathassanak. Ez, amint láttuk, a hatalmi pozícióban lévő csoport frusztrációinak és erősödő ellenszenvének egyik fontos forrása volt Gyöngyöspatán. Erre hivatkozott az a rendpárti politika, amelynek hatalomra kerülése után szinte teljesen felszámolták az együttélést lehetővé tevő közös intézményeket, és háttérbe szorultak a hídszerepet betölteni képes személyek is.

Elemzésünkben azt is kiemeltük, hogy a konfliktus kirobbanásában kulturális-ideológiai síkon zajló folyamatok is fontos szerepet játszottak. Itt arra emlékeztetnénk, hogy az erős paraszti tradíciókat - és ebből adódóan rendies gon- 
dolkodásmódot - őrző többségi lakosság egy újfajta beszédmód kidolgozásával kísérelte meg hagyományos politikai és gazdasági erőfölényét helyreállítani és a gettó lakosságát az általa ellenőrzött erőforrásoktól elzárni. Ennek érdekében hozták létre a munkához és tulajdonhoz füződő viszony - és egyéb értékek - mentén alapvető és áthidalhatatlan különbséget az „érdemes” és „érdemtelen” szegények között. Hogy ez a különbség az etnicitás nyelvén született meg, részben annak tudható be, hogy a mélyszegénységben élők között - történelmi okok miatt nagyobb arányban vannak a (mások vagy maguk által) romáknak/cigányoknak tekintett emberek. Részben pedig annak, hogy a többségi „magyar”, „paraszti” vagy egyes esetekben „fehér” önkép és tudat felépítését vagy rehabilitációját sokan egy morálisan alsóbbrendűnek tételezett „másikkal” - a „,cigánnyal” - szemben tudták csak megvalósítani.

\section{IRODALOM}

Albert, G. (2012): Anti-Gypsysm and Extreme Right in the Czech Republik. In: Stewart, M. (ed.) (2012): The Gypsy Menace: Populism and the New Anti-Gypsy Politics. London: Hurst, $137-165$.

Bíró Nagy A. - Dúró J. - Hajdú A. - Róna D. (2011): Nemzet és radikalizmus. In: Lánczi A. (ed.): Nemzet és radikalizmus. Budapest: Századvég, 7-34.

Feischmidt M. - Szombati K. (2017a): Understanding the Rise of the Far Right from a Local Perspective: Structural and Cultural Conditions of Ethno-traditionalist Inclusion and Racial Exclusion in Rural Hungary. Identities. Global Studies in Culture and Power. 24, 3, 313-331. DOI: 10.1080/1070289X.2016.1142445, https://bit.ly/2q7E4Hh

Feischmidt M. - Szombati K. (2017b): Cigányellenesség és szélsőjobboldali politika a magyar társadalomban: Gyöngyöspata és a hozzá vezető út. Esély. 1, 74-90. http://www.esely.org/kiadvanyok/2013_1/feischmidt.pdf

Holmes, D. (2000): Integral Europe: Fast-Capitalism, Multiculturalism, Neofascism. Princeton: Princeton University Press

Horváth K. - Kovai C. (2010): A cigány-magyar különbségtétel alakulása egy észak-magyarországi faluban. anBlokk, 4, 28-31. http://epa.oszk.hu/02700/02725/00003/pdf/EPA02725_anblokk_2010_4_039-041.pdf

Kalb, D. - Halmai G. (ed.) (2011): Headlines of Nation, Subtexts of Class: Working Class Populism and the Return of the Repressed in Neoliberal Europe. New York: Berghahn

Minkenberg, M. (2000): The Renewal of the Radical Right: Between Modernity and Antimodernity. Government and Opposition, 35, 2, 170-188. DOI: 10.1111/1477-7053.00022, https:// www.researchgate.net/publication/230488894_The_Renewal_of_the_Radical_Right_Between Modernity_and_Anti-modernity

Nemzeti és Etnikai Kisebbségi Jogok Országgyülési Biztosa (2011): A nemzeti és etnikai kisebbségi jogok országgyülési biztosának jelentése a 2011 márciusban történt gyönygöspatai események és hasonló jelenségek veszélyeiröl. Budapest, 2011. április 19. http://www.kisebbsegiombudsman.hu/data/files/203198066.pdf

Ökopolisz Alapítvány (2012): Gyöngyöspata 2011: A magyarországi szélsőjobboldal laboratóriuma. Budapest: Ökopolisz Alapítvány 
Rydgren, J. (2007): The Sociology of the Radical Right. Annual Review of Sociology, 33, 241-262. DOI: $\quad 10.1146 /$ annurev.soc.33.040406.131752, http://jensrydgren.com/Sociology\%20of $\% 20$ the\%20radical\%20right.pdf

Stewart, M. (2012): Populism, Roma and the European Politics of Cultural Difference. In: Stewart, M. (ed.) (2012): The Gypsy Menace: Populism and the New Anti-Gypsy Politics. London: Hurst, $3-23$.

Zolnay J. (2012): Abusive Language and Discriminatory Measures in Hungarian Legal Policy. In: Stewart, M. (ed.) (2012): The Gypsy Menace: Populism and the New Anti-Gypsy Politics. London: Hurst, 25-42. 